\title{
Hatching Distribution and Embryo Mortality of Eggs Laid by Broiler Breeders of Different Ages
}

\section{Author(s)}

Almeida JG

Vieira SL

Reis RN

Berres J

Barros R

Ferreira AK

Furtado FVF

Departamento de Zootecnia

Universidade Federal do Rio Grande do Sul

Mail Address

Sergio Luiz Vieira

Faculdade de Agronomia - UFRGS

Av. Bento Gonçalves, 7712

91.540-000. Porto Alegre, RS, Brazil

Phone/Fax: +55 5133087419

E-mail: slvieira@ufrgs.br

\section{Keywords}

Broiler chicks, embryo mortality, incubation, post-hatching management.

Projeto com suporte financeiro da FAPERGS.

\section{ABSTRACT}

This study investigated the hatching distribution of eggs from broiler breeders of different ages in distinct periods of incubation. Eggs were incubated in a single-stage experimental incubator. A number of 3.510 eggs were distributed into 3 treatments with 13 replicates of 90 eggs each. Treatments corresponded to breeder age: young (34 weeks), intermediate-age (44 weeks) and old (72 weeks) breeders. Eggs were transferred to the hatcher at 432 incubation hours, hatching was first checked at 449 hours, after which the number of hatched chicks was counted every 6 hours up to 515 incubation hours. After each count, hatched chicks were removed from the hatcher. Data were submitted to analysis of variance using measures repeated. A significant interaction between breeder age and incubation time was found. The total period required to hatch all incubated fertile eggs was not influenced by breeder age, which, however, affected hatching distribution. Eggs from old breeders hatched later as compared to young and intermediate-age breeders. More than $71 \%$ of the eggs had already hatched at 485 incubation hours, and $94 \%$ at 491 hours. Eggs laid by old breeders presented higher infertility and total embryo mortality, resulting in lower hatching percentage.

\section{INTRODUCTION}

Commercial hatcheries apply incubation periods of approximately 504 hours, which supposedly maximizes hatching. However, many chicks hatch earlier, and therefore remain for several hours with no food or water before being removed from the hatcher. According to Vieira \& Pophal (2000), broiler chicks hatch in a time range of 480 to 510 hours. Factors such as breeder age, hatchable egg storage time and temperature, egg weight, season, and bird type influence total incubation time (Wilson, 1991).

Fanguy et al. (1980) and Wyatt et al. (1985) showed that the longer the chicks remain in the hatcher, the worse is their live performance. Wyatt et al. (1985) observed that chicks that remained in the hatching trays for 14 to 32 hours were $5-32 \%$ lighter than those removed 7 hours after hatching. Nir \& Levanon (1993) and Sklan et al. (2000) found higher percentage of body weight loss, from 5 to $15 \%$, which continued up to market age. Halevy et al. (2000) showed that post-hatching fasting lead to lower weight gain and breast meat accretion capacities.

Chicks that hatch and are immediately removed from the hatcher and supplied with water and feed present better performance as compared to chicks that remain in the hatcher longer or take longer to have access to feed and water after hatching (Williams et al., 1951; Kingston, 1979; Fanguy et al., 1980; Hager \& Beane, 1983; Wyatt et al., 1985). Gonzales et al. (2003) showed that weight loss, early mortality, 


\section{Almeida JG, Vieira SL, Reis RN, Berres J, Barros R, Ferreira AK, Furtado FVF}

Hatching Distribution and Embryo Mortality of Eggs Laid by Broiler Breeders of Different Ages lack of flock uniformity, and culling significantly increase after 48 hours of fasting.

The period immediately after hatching is critical for the development of the immune and gastrointestinal systems. During the first days of the bird's life, the small intestine grows five times faster than the rest of the body and small intestine microvilli grow significantly faster in birds supplied with water and feed immediately after hatching (Dibner et al., 1998).

Broiler performance during the first week of life is highly correlated with performance at market age (Nitsan, 1995). Therefore, any factor that reduces initial weight gain can affect body weight at market age.

Wilson (1991) reported that eggs laid by old breeders tend to have long incubation periods, as well as those from breeders at the onset of lay. According to Marques (1994), eggs from younger breeders tend to have a shorter incubation period. Opposite results were reported by Shanawany (1984), who observed that eggs laid by old breeders have shorter incubation periods as compared to those laid by young breeders. That author concluded that from old breeder eggs present earlier embryo development during the first weeks of lay as they remain longer in the oviduct, leading to earlier hatching. These findings are consistent with studies of McNally \& Byerly (1936), Smith \& Bohren (1975), and Burton \& Tullet (1985), who observed shorter incubation periods as breeders aged.

Pedroso et al. (2005) observed that eggs laid by 37week-old breeders hatched 9 hours later than those laid by 32-week-old breeders. In addition, egg weight had no influence on incubation period, which was related to breeder age. These results agree with Vieira et al. (2005), who observed that breeder age influences the time required for hatching. Working with breeders of different ages $(29,40$, and 59 weeks), those authors found that at 485 hours of incubation more than $90 \%$ of the eggs had already hatched. Reis et al. (1997) studied 33- and 49-week-old breeders, and verified that $56 \%$ of the eggs hatched at 485 hours, and at 490 hours, more than $94 \%$ had hatched in a total incubation period of 504 hours. Hudson et al. (2004) worked with breeders of different ages $(29 ; 41 ; 53$ e 65 weeks), and observed that $27 \%$ of all eggs hatched at 480 hours, and that $86 \%$ at 491 hours. According to those authors, the low hatching rate at 480 hours was due to young breeders' (29 weeks) eggs - only $10 \%$ had hatched at that time. That study also found that the time required for hatching increased as breeders aged - eggs from 53-week-old breeders or older presented longer incubation periods. This is consistent with the finding of Olsen (1942); Williams et al. (1951), and Wilson (1991), who also verified longer incubation periods as breeders aged. Vieira et al. (2005) observed that $90 \%$ of eggs hatched at 485 hours remained for 19 hours in the hatcher to allow the remaining $10 \%$ to hatch.

Embryo mortality rates must be reduced to improve hatching rates. It is essential to determine its causes and to solve the problems that may occur from laying to hatching.

Breeders with extremes in age usually present high percentage of infertile eggs (Schmidt et al. 2003) and high total embryo mortality (McDaniel et al., 1979; Wilson, 1991; Reis et al., 1997; Lapão et al., 1999; Hudson et al., 2004).

The objective of the present study was to determine possible differences in the time required for hatching and embryo mortality of eggs laid by heavy breeders of different ages.

\section{MATERIAL AND METHODS}

A total of 3.510 Isa Vedette eggs laid by breeders of three different ages (34, 44, and 72 weeks) were collected in the same farm and were laid on the same day. Eggs were incubated in a single-stage machine in the incubator of the lab of the Animal Science Department of the Federal University of Rio Grande do Sul. Eggs were hourly turned, and submitted to $37.5^{\circ} \mathrm{C}$ temperature and $60 \%$ relative humidity $(\mathrm{RH})$ in the incubator and $36.5^{\circ} \mathrm{C}$ and $65 \% \mathrm{RH}$ in the hatcher after, transference on day 18 of incubation. Each breeder age was subdivided in three treatments of 13 replicates each, with 90 eggs per replicate randomly distributed in the machine. The number of hatched chicks started to be counted at $449 \mathrm{~h}$ of incubation at regular 6 -h intervals up to $515 \mathrm{~h}$. Two eggs per replicate $(n=78)$ were collected to determine albumen, yolk, and eggshell ratios. Humidity loss during incubation was calculated as the egg weight difference between egg weight at the time of incubation and egg weight time of transference to the hatcher. Egg weight to chick weight ratio was determined by weighing $20 \%$ of hatched chicks in each replicate. All birds that hatched up to 485 incubation hours in each replicate were weighed, and 2 were sacrificed; the remaining birds were kept in the hatcher and weighed again at 515 incubation hours, when 2 other birds per replicate were sacrificed to weigh the yolk sac. This allowed the determination of chick weight to yolk sac weight ratio and to verify the effect of $30 \mathrm{~h}$ of fasting on these 
Almeida JG, Vieira SL, Reis RN, Berres J, Barros R, Ferreira AK, Furtado FVF
Hatching Distribution and Embryo Mortality of Eggs Laid by Broiler Breeders of Different Ages parameters. Non-hatched eggs from each repllicate was analyzed at the end of the experimental period for embryo mortality causes and period, which was divided in early (1-7 days), intermediate (7-14 days), and late (14 a 21 days) mortality.

The study model included "time", as the 6-h intervals when the completely hatched chicks were removed from the hatcher (incubation period). Data to analysis of variance using repeated measures over time in the Mixed Procedures of SAS (1998) software. Variance and covariance structures were determined according to Akaike's evaluation criterion (1987), and compound symmetry (CS) was the one that best fit the data. This structure assumes variance homogeneity for each age. Differences among means were verified by the test of $(p<0.05)$.

\section{RESULTS AND DISCUSSION}

Hatching time results as a function of breeder age are shown in Tables and Graphs 1 and 2. The tables show significant interaction between breeder age and hatching time, indicating that the time required for hatching depends on breeder age. In Table 1 and Graph 1 , the data are based on the number of hatched chicks, and the hatching percentage at each evaluated time is added (cumulative). Table 1 shows that the first hatchings happened at 461h, from eggs of old and intermediate-age breeders. Young breeders' eggs hatched later, at 467 incubation hours. Eggs from intermediate-age breeders presented higher hatching percentage at 467 incubation hours as compared to those of young and old breeders, which were not significantly different from each other.

After 473 incubation hours, the hatching percentage of young breeders' eggs was statistically similar to those laid by intermediate-age breeders, and remained as such until the end of the experimental period (515 hours). The hatching percentage of old breeders' egg was the lowest up to 485 incubation hours, after which there were no differences.

Difference in hatch distribution between did not affect total incubation period. At 485 incubation hours, $71 \%$ of the eggs had hatched. It was observed that eggs from old breeders lowered this average, with only $58 \%$ hatching at that time as compared to $77 \%$ of young and intermediate-age breeders' eggs.

Based on this observation, it is suggested that if old breeders' eggs are incubated a few hours before the eggs of young and intermediate-age breeders, hatchings could be synchronized at 485 or 491 incubation hours. Therefore, chicks can be removed from the hatcher in two different steps: at 485 or 491 hours and at 515 hours. In the present experiment, $94 \%$ of the hatched chicks could be removed at 491 incubation hours, 24 hours before the final incubation time. The remaining $6 \%$ could be removed at 515 incubation hours, thereby preserving chick quality.

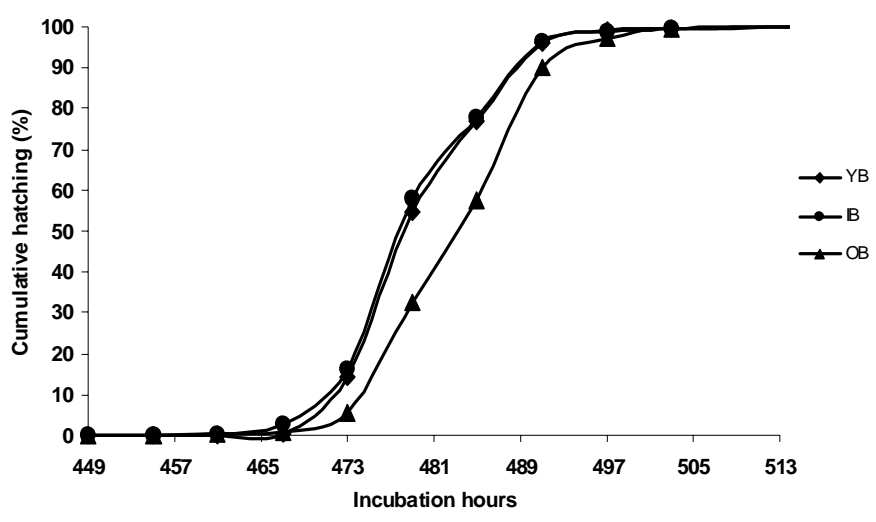

Graph 1 - Cummulative hatching of chicks derived from broiler breeders of different ages (34, 44 e 72 weeks), \% relative to total number of hatched chicks.

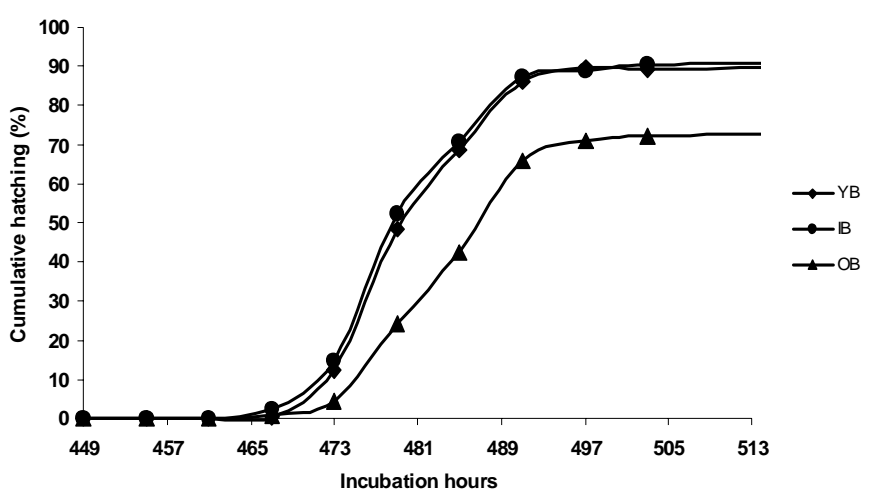

Graph 2 - Cummulative hatching of chicks derived from broiler breeders of different ages (34, 44, and 72 weeks), \% relative to total number of incubated eggs.

Table 2 and Graph 2 show hatching percentage to the number of incubated eggs, and reflect the results presented in Table 1 and Graph 1. Table 2 shows the differences in hatching percentage at 515 incubation hours according to breeder age. It is observed that young and intermediate-age breeders' eggs presented the best hatching results, and were not statistically different. The worst results were found for old breeders' eggs, which hatching percentage was $18 \%$ lower as compared to the eggs from breeders of the other ages.

These results are consistent with those of Pedroso et al. (2005) and Vieira et al. (2005), who observed a 
significant relationship between hatching distribution and breeder age, but disagree with the studies of Reis et al. (1997) and Hudson et al. (2004), who did not find such relationship.

\begin{tabular}{|c|c|c|c|c|c|c|}
\hline \multirow[b]{2}{*}{$\begin{array}{l}\text { Incubatiol } \\
\text { (hours) }\end{array}$} & \multicolumn{6}{|c|}{$\begin{array}{l}\text { Table1 - Cummulative aatchings of chicks derived from broiler } \\
\text { breeders of different ages ( } 34,44 \text {, and } 72 \text { weeks), \% relative to } \\
\text { total number of hatched chicks. }\end{array}$} \\
\hline & \multicolumn{3}{|c|}{$\begin{array}{cc}n & \text { Breeder } \\
\mathrm{P} & \mathrm{YB}\end{array}$} & OB & $\begin{array}{l}\text { Incubation } \\
\text { (mean) }\end{array}$ & $\begin{array}{ll}\text { n } & \text { CV } \\
& (\%)\end{array}$ \\
\hline 449 & 1,0000 & 0,00 & 0,00 & 0,00 & 0,00 & 0,00 \\
\hline 455 & 1,0000 & 0,00 & 0,00 & 0,00 & 0,00 & 0,00 \\
\hline 461 & 0,5207 & 0,00 & 0,21 & 0,23 & $0,15^{e}$ & 384,06 \\
\hline 467 & 0,0273 & $0,52^{b}$ & $2,74^{\mathrm{a}}$ & $0,82^{\mathrm{ab}}$ & $1,36^{e}$ & 171,37 \\
\hline 473 & 0,0435 & $14,09^{a}$ & $16,21^{\mathrm{a}}$ & $5,65^{b}$ & $12,01^{d}$ & 99,57 \\
\hline 479 & 0,0115 & $54,76^{a}$ & $57,95^{a}$ & $32,63^{b}$ & $48,45^{c}$ & 50,08 \\
\hline 485 & 0,0124 & $76,98^{a}$ & $77,68^{a}$ & $57,68^{b}$ & & 28,40 \\
\hline 491 & 0467 & $96,03^{a}$ & $96,35^{a}$ & $89,98^{b}$ & $94,12^{\mathrm{a}}$ & 7,92 \\
\hline 497 & 0,0782 & 99,14 & 98,95 & 97,30 & $98,47^{a}$ & 2,33 \\
\hline 503 & 0,9328 & 99,43 & 99,57 & 99,52 & $99,50^{a}$ & 0,93 \\
\hline 515 & 1,0000 & 100,00 & 100,00 & 100,00 & $100,00^{a}$ & 0,00 \\
\hline Breeder & $-49,18^{a}$ & $49,98^{a}$ & $43,98^{b}$ & $-94,12$ & & \\
\hline Breeder & & & $\begin{array}{l}\mathbf{P} \\
0,000\end{array}$ & & & \\
\hline Time & & & 0,000 & & & \\
\hline B X T & & & 0,000 & & & \\
\hline
\end{tabular}

Means followed by the same letter in the same row are not statistically different by the test of Tukey at $5 \%$ probability. Where: $Y B=$ young breeder (34 weeks); IB = intermediate-age breeder (44 weeks); OB $=$ old breeder (72 weeks). Comparison of means within the same column.

Table $\mathbf{2}$ - Cummulative aatchings of chicks derived from broiler breeders of different ages $(34,44$, and 72 weeks), \% relative to total number of incubated eggs.

\begin{tabular}{|c|c|c|c|c|c|c|}
\hline \multicolumn{2}{|c|}{ Incubation } & \multicolumn{3}{|l|}{ Breeder } & \multirow{2}{*}{\multicolumn{2}{|c|}{$\begin{array}{cc}\begin{array}{c}\text { Incubation } \\
\text { (mean) }\end{array} & \text { CV } \\
\end{array}$}} \\
\hline (hours) & $\mathbf{P}$ & YB & IB & OB & & \\
\hline 449 & 1,0000 & 0,00 & 0,00 & 0,00 & 0,00 & 0,00 \\
\hline 461 & 0,4946 & 0,00 & 0,19 & 0.17 & $0.12^{\mathrm{e}}$ & 368,89 \\
\hline 473 & 0,0213 & $12,24^{\mathrm{ab}}$ & $14,68^{a}$ & $4,22^{b}$ & $10,38^{d}$ & 99,24 \\
\hline 485 & 0,0001 & $68,79^{a}$ & $70,45^{a}$ & $42,44^{b}$ & $60,56^{b}$ & 31,84 \\
\hline 497 & 0,0001 & $89,87^{a}$ & $89,07^{a}$ & $70,85^{b}$ & $83,26^{a}$ & 12,65 \\
\hline 515 & 0,0001 & $89,86^{a}$ & $90,81^{a}$ & $72,70^{b}$ & $84,46^{a}$ & 11,65 \\
\hline Breeder & & & $\begin{array}{l}\mathbf{P} \\
0,0001\end{array}$ & & & \\
\hline B $\times$ T & & & 0,0001 & & & \\
\hline
\end{tabular}

Means followed by the same letter in the same row are not statistically different by the test of Tukey at $5 \%$ probability. Where: $Y B=$ young breeder (34 weeks); IB = intermediate-age breeder (44 weeks); $O B$ $=$ old breeder (72 weeks). Comparison of means in the same column.

Vieira et al. (2005) also found that intermediateage breeders' eggs started to hatch earlier than those laid by breeders with other ages, with the first hatchings occurring at 449 incubation hours - 12 hours earlier than those reported in the present study. Those authors worked with multiple-stage incubators, and the heat generated by older embryos may have contributed to accelerate the development of a small percentage of eggs, thereby resulting in those very early hatchings. They also found the hatching distribution of old breeders' eggs was concentrated in the final periods of incubation, which is consistent with the findings of the present study. However, those authors observed late hatchings also for young breeders' eggs. Wilson (1991) and Marques (1994) also found a longer total incubation period for eggs from breeders at the onset of lay.

Hatching distribution, according to Wilson (1991), depends on breeder age, hatchable egg storage time and temperature, incubation temperature, egg weight, season, and chicken type. According to Campos (2000), the type of incubator - single or multiple stages - also influences hatching distribution. Multiple-stage equipment incubates embryos in different developmental stages, making embryos in later developmental stages interfere with the metabolism of embryos in earlier developmental stages. Salazar (2000) observed that high-capacity incubators also tend to present wider variation in total incubation time.

Meijerhof (2003) identified incubator air flow as a factor that may influence hatching distribution or total time required for all eggs to hatch. According to that author, incubators must have efficient air circulation in the internal environment in order to efficiently heat eggs during early embryo development and to remove the excessive heat produced by the embryos after day 10 of incubation. The efficiency of this process is reduced as incubator capacity increases.

Rosa \& Ávila (2000) added incubation humidity as a factor that may contribute to variations in incubation time. According to those authors, eggs of breeders older than 50 weeks of age present high water content in the albumen, thin eggshell, and lower area to volume ratio, thereby hindering gas exchange. Therefore higher water loss $(14-15 \%)$ than the recommended values $(10-12 \%)$ is required to supply higher oxygen levels to the embryo, resulting in faster embryo growth and shorter incubation periods.

O'Connor (1984) correlated egg weight with incubation time: when egg weight doubles, incubation time increases $16 \%$. This finding is consistent with the results of Vieira et al. (2005), who observed that the time required for hatching increased in heavy eggs as compared to lighter eggs of intermediate-age breeders. On the other hand, Pedroso et al. (2005) did not find significant correlations between egg weight and hatching time. 


\section{Almeida JG, Vieira SL, Reis RN, Berres J, Barros R, Ferreira AK, Furtado FVF}

Hatching Distribution and Embryo Mortality of Eggs Laid by Broiler Breeders of Different Ages
Baião et al. (2005) found that laying hour influences incubation time of broiler chicks. Those authors observed that chicks derived from eggs of the fifth daily egg collection hatched earlier than those from the first collection, which could be explained by the fact that the former remain longer in the hen's reproductive tract, and thereby submitted to higher temperature, accelerating embryo development after lay. These findings are not consistent with those of Fasenko et al. (1992), who observed that eggs from the first collection were heavier, indicating that their embryos were more developed.

All these variation factors contribute to the differences in the hatching distribution results reported in literature. In the present experiment, $71 \%$ of the eggs had hatched until 485 incubation hours, and $94 \%$ until 491 incubation hours. Reis et al. (1997) observed that $56 \%$ of the eggs had hatched at 485 hours and $94 \%$ at 490 hours, whereas Hudson et al. (2004) reported $60 \%$ hatching at 480 hours and $86 \%$ at 491 incubation hours.

In general, longer (Olsen, 1942; Williams et al., 1951; Hudson et al., 2004; Vieira et al., 2005; Pedroso et al., 2005), shorter (McNally \& Byerly, 1936; Smith \& Bohren, 1975; Shanawany, (1984); Burton \& Tullet, 1985) or similar (Reis et al., 1997) incubation periods as breeders aged were found in literature.

Long fasting periods stimulate the production of corticosterone, a hormone known for its strong inhibitor effect on immune cells. Early chick feeding stimulated the development of the bursa and the intensive production of lymphocytes (Bigot et al., 2001).

Table 3 shows the relations between egg components and breeder age. Egg weight linearly increased with breeder age, whereas the albumen to egg weight ratio was not influenced by breeder age. Significant relations were recorded for yolk weight and eggshell weight, with higher relative yolk weight and lower relative eggshell weight for old breeders' eggs, while eggs from young and intermediate-age breeders did not present any differences in these parameters.

The higher eggshell percentage relative to egg weight, followed by higher albumen percentage in young breeders' eggs, and the higher yolk percentage in old breeders' eggs were also found by Tullet \& Burton (1982), Vieira et al. (2005), Gomes et al. (2005a), and Ferreira et al. (2005).

Table 4 lists the relative data of the incubation waste analysis. The hatchability and the fertility of old breeders' eggs were lower than those of young and intermediate-age breeders, which were not significantly different.

\begin{tabular}{|c|c|c|c|c|}
\hline Breeder & $\begin{array}{c}\text { Egg weight, } \\
\text { g }\end{array}$ & $\begin{array}{c}\text { Albumen, } \\
\%\end{array}$ & $\begin{array}{c}\text { Yolk, } \\
\%\end{array}$ & $\begin{array}{c}\text { Eggshell, } \\
\%\end{array}$ \\
\hline YB & $58.04^{c}$ & 57.20 & $28.75^{b}$ & $12.83^{a}$ \\
\hline $\mathrm{IB}$ & $64.17^{b}$ & 57.33 & $29.84^{b}$ & $12.35^{a}$ \\
\hline OB & $72.89^{a}$ & 56.58 & $31.59^{a}$ & $11.33^{b}$ \\
\hline CV, \% & 11.88 & 4.65 & 8.17 & 10.69 \\
\hline $\mathbf{P}$ & 0.0001 & 0.6203 & 0.0005 & 0.0004 \\
\hline
\end{tabular}

Genetic line: Isa-Vedette. Means followed by the same letter in the same column are not statistically different by the test of Tukey at $5 \%$ probability. Where: $Y B=$ young breeder (34 weeks); $I B=$ intermediate-age breeder (44 weeks); OB = old breeder (72 weeks).

\begin{tabular}{|c|c|c|c|c|}
\hline $\begin{array}{l}\text { Breeder } \\
\text { Early }\end{array}$ & $\begin{array}{l}\text { Hatch } \\
\text { Interm. }\end{array}$ & $\begin{array}{c}\text { Hatchab. } \\
\text { Late }\end{array}$ & $\begin{array}{l}\text { Fert. } \\
\text { PD }\end{array}$ & $\begin{array}{l}\text { Inf. } \\
\text { PL }\end{array}$ \\
\hline Young & $87,86^{a}$ & $93,46^{a}$ & $95,60^{a}$ & $4,40^{b}$ \\
\hline $3,69^{a b}$ & 0,57 & $0,71^{b}$ & 0,14 & 0,43 \\
\hline Interm. & $88,79^{a}$ & $93,63^{a}$ & $96,43^{a}$ & $3,57^{b}$ \\
\hline $3,41^{b}$ & 0,32 & $1,46^{\mathrm{ab}}$ & 0,32 & 0,32 \\
\hline Old & $70,34^{b}$ & $86,30^{b}$ & $87,95^{b}$ & $12,04^{a}$ \\
\hline $5,91^{a}$ & 0,68 & $3,18^{a}$ & 0,23 & 0,45 \\
\hline CV, \% & 12,22 & 4,29 & 4,46 & 69,55 \\
\hline 48,09 & 113,43 & 107,21 & 205,20 & 167,76 \\
\hline $\mathbf{P}$ & 0,0001 & 0,0001 & 0,0001 & 0,0001 \\
\hline 0,0431 & 0,5651 & 0,0280 & 0,7710 & 0,9413 \\
\hline
\end{tabular}

Where: Hatchb = hatchability, Fert. = fertility; Inf. = infertility; Early = early embryo mortality (1-7 days); Interm. = intermediate embryo mortality (8-14 days); Late = late embryo mortality (15-21 days); PD = pipped and dead; $\mathrm{PL}=$ pipped and alive. Means followed by the same letter in the same column are not statistically different by the test of Tukey at $5 \%$ probability.

Eggs from young and old breeders presented higher early embryo mortality percentages. Late embryo mortality was higher in old breeders' eggs. Eggs from intermediate-age breeders had the lowest general mortality rate. Live and dead pipped chick percentage and intermediate embryo mortality were not influenced by breeder age. In general, old breeder's eggs presented higher infertility and total embryo mortality $(22.49 \%)$ as compared to young $(9.94 \%)$ and intermediate-age breeders' eggs $(9.40 \%)$. These findings are consistent with those reported by Mcdaniel et al. (1979), Wilson (1991), Reis et al. (1997), Lapão et al. (1999), and Hudson et al. (2004).

Understanding the physiological peculiarities of each breeder age, as well as embryo development will aid the design of new incubation management practices that can contribute to reduce total embryo mortality.

Table 5 presents egg weight loss during incubation and the relation between egg weight and chick weight 


\section{Almeida JG, Vieira SL, Reis RN, Berres J, Barros R, Ferreira AK, Furtado FVF}

Hatching Distribution and Embryo Mortality of Eggs Laid by Broiler Breeders of Different Ages at hatching. No differences were found for the relation between egg weight loss during incubation and breeder age, with an average rate of $11 \%$. This is not consistent with the results of Gomes et al. (2005b) and Michalsky et al. (2005ab), who observed higher humidity loss in old breeders' eggs.

\begin{tabular}{|c|c|c|c|c|}
\hline \multicolumn{5}{|c|}{$\begin{array}{l}\text { Table } 5 \text { - Egg weight, humidity loss during incubation, chick } \\
\text { weight at hatching and egg weight relative to chick weight at } \\
\text { hatching as a function of breeder age. }\end{array}$} \\
\hline Breeder & EW, g & HL, \% & WH, g & CRW, \% \\
\hline Young & $58,00^{c}$ & 10,92 & $41,80^{b}$ & 72,09 \\
\hline Interm. & $61,72^{b}$ & 10,80 & $43,70^{b}$ & 70,81 \\
\hline Old & $66,28^{a}$ & 11,15 & $47,25^{a}$ & 72,45 \\
\hline CV, \% & 6,02 & 3,83 & 5,70 & 3,21 \\
\hline $\mathbf{P}$ & 0,0017 & 0,7887 & 0,0233 & 0,7023 \\
\hline
\end{tabular}

Where: $\mathrm{PO}=$ Egg weight; $\mathrm{HL}=$ humidity loss during incubation; $\mathrm{WH}$ = chick weight at hatching; $C R W=$ egg weight relative to chick weight at hatching. Means followed by the same letter in the same column are not statistically different by the test of Tukey at $5 \%$ probability.

Chick weight at hatching was higher for those derived from old breeders' eggs, whereas no difference was found for those derived from young and intermediate-age breeders' eggs. Chick weight to egg weight ratio was not affected by breeder age, with an average of $72 \%$. These data are consistent with those of Shanawany (1984) and Yannakopoulos (1988), but are different from the findings of Gomes et al. (2005a), who observed a higher ratio for chicks from young breeders. Campos et al. (2003) verified a 73\% ratio between egg weight and chick weight, as did Vieira et al. (2005).

Table 6 presents the relations among chick weight, yolk-sac weight, and breeder age of chicks that hatched at 485 hours and that were removed from the hatcher at 515 hours. It is observed that 30 hours after hatching, chick weight continued to have a linear relation with breeder age. However, weight loss due to dehydration and to the utilization of yolk sac reserves changed: chicks derived from old and intermediateage breeders lost more weight (average $5.56 \%$ ) than those derived from young breeders (2.92\%). As to yolksac weight at 485 hours, chicks derived from intermediate-age breeders used this reserve more $(41.10 \%)$ than those derived from young and old breeders, which average utilization was $23 \%$. Wyatt et al. (1985) and Nir \& Levanon (1993) reported 5 to $32 \%$ body weight loss in chicks kept for 14 to 32 hours in the hatcher after hatching.

Breeder age influenced yolk sac weight relative to chick weight. Chicks from old breeders presented higher relative yolk sac weight $(16 \%)$ as compared to those from young breeders $(10.41 \%)$. Chicks from intermediate-age breeders presented an intermediate value $(13.43 \%)$, which was not different from young or old breeders. Vieira et al. (2005) observed that chicks from old breeders, and heavy chicks from intermediateage breeders presented higher yolk sac weight $(16.58 \%)$ as compared to chicks from young breeders or those derived from light eggs laid by intermediateage breeders (14.88\%). These data indicate that yolksac weight may be also be related to egg weight, and not only to breeder's age. These results are consistent with those of Gomes et al. (2005), who observed heavier yolk sacs in chicks derived from old breeders $(16.19 \%)$ as compared to those derived from young (13.67\%) and intermediate-age breeders (15.74\%). Murakami et al. (1991) recorded a value of $10 \%$ for this relation, whereas Sklan \& Noy (2000) observed $20 \%$.

\begin{tabular}{|c|c|c|c|c|c|c|}
\hline Breeder & WA, $g$ & WB, $\mathrm{g}$ & Diff., \% & YSA, \% & YSB，\% & Diff., \% \\
\hline Young & $39,73^{c}$ & $38,57^{c}$ & 2,92 & $10,41^{b}$ & 8,34 & 19,88 \\
\hline Interm. & $44,87^{\mathrm{bA}}$ & $42,23^{\mathrm{bB}}$ & 5,88 & $13,43^{a b}$ & 7,91 & 41,10 \\
\hline Old & $47,67^{\mathrm{aA}}$ & $45,17^{\mathrm{ab}}$ & 5,24 & $15,78^{a}$ & 11,50 & 27,12 \\
\hline
\end{tabular}

WA $=$ weight of chicks hatched at 485 hours; $W B=$ weight of chicks hatched 485 hours and removed from the hatcher at 515 hours (30 hours after hatching); YSA = relative yolk sac weight at 485 hours; YSB = relative yolk sac weight of chicks hatched 485 hours and removed from the hatcher at 515 hours (30 hours after hatching). Means followed by the same letter in the same column are not statistically different by the test of Tukey at $5 \%$ probability.

\section{CONCLUSIONS}

In the present experiment, $71 \%$ of the chicks hatched at 485 incubation hours or less, and $94 \%$ had hatched at 491 hours. It is suggested that chicks should be removed at least once before 510 incubation hours, which is the commonly used incubation period, thereby reducing the period of time most birds are submitted to water and feed fasting.

Breeder age did not influence total time required for all eggs to hatch, but affected hatching distribution within this period.

Eggs laid by old breeders presented higher percentages of infertile eggs and total embryo mortality, resulting in a lower hatchability percentage for those birds. 


\section{Almeida JG, Vieira SL, Reis RN, Berres J, Barros R, Ferreira AK, Furtado FVF}

Hatching Distribution and Embryo Mortality of Eggs Laid by Broiler Breeders of Different Ages

\section{REFERENCES}

Akaike H. Factor-analysis and AIC. Psychometrika 1987; 52(3):317332.

Baião LEC, Costa ES, Silva PL. Efeito do horário de postura sobre o período de nascimento de pintos de corte. Revista Brasileira de Ciência Avícola 2005; 3(supl):6.

Bigot $\mathrm{K}$, Tesseraud S, Taouis M. The relation of egg weight to chick weight at hatching. Productions Animales 2001; 14:219-230.

Burton FG, Tullet SG. The effects of egg weight and shell porosity on the growth and water balance on the chicken embryo. Comparative Biochemistry and Physiology 1985; 81A:377-385.

Campos EJ. Avicultura: razões fatos e divergências. Belo Horizonte: FEP-MVZ; 2000.

Campos EJ, Santos JEC. O efeito de linhagens sobre o desenvolvimento embrionário. In: Macari M, Gonzales E, editores. Manejo da incubação. 2.ed. Jaboticabal: FACTA; 2003; p. 353361.

Dibner JJ, Knight CD, Kitchell ML, Atwell CA, Downs AC, Ivey FJ. Early feeding and the development of the immune system. Journal of Applied Poultry Research 1998; 7:425-436.

Fanguy RC, Misra LK, Vo KV. Effect of delayed placement on growth performance of commercial broilers. Poultry Science 1980; 59:12151220.

Fasenko GM, Hardin RT, Robinson FE.Variability in preincubation embryonic development in domestic fowl. Poultry Science 1992; 71:1374-1383.

Gomes FS, Santos GCF, Silva PL. Efeito da linhagem e idade de reprodutoras pesadas na qualidade dos pintos de um dia. Revista Brasileira de Ciência Avícola 2005a; 3(supl):19.

Gomes FS, Santos GCF, Silva PL. Efeito da linhagem e idade de reprodutoras pesadas na qualidade dos ovos incubáveis. Revista Brasileira de Ciência Avícola 2005b; 3(supl):20.

Gonzales E, Kondo N, Saldanha ESPB, Loddy MM, Careghi C, Decuypere E. Performance and physiological parameters of broilers chickens subjected to fasting on the neonatal period. Poultry Science 2003; 82:1250-1256.

Hager JE, Beane WL. Posthatch icubation time on early growth of broiler chicks. Poultry Science 1983; 62:247-254.

Halevy O, Geyra A, Barak M, Uni Z, Sklan D. Early posthatch starvation decreases satellite cell proliferation and skeletal muscle growth in chicks. Journal of Nutrition 2000; 130:858-864.

Hudson BP, Fairchild BD, Wilson JL, Dozier WA, Buhr RJ. Breeder age and zinc source in broiler breeder hen diets on progeny characteristics at hatching. Journal of Applied Poultry Research 2004; 13:55-64. Australian Veterinary Journal 1979; 55:418-421.

Lapão C, Gama LT, Soares MC. Effects of broiler breeder age and lengh of egg storage on albumen characteristics and hatchability. Poultry Science 1999; 78:640-645.

Marques, D. Fundamentos básicos de incubação industrial. 2.ed. São Paulo: CASP S/A; 1994.

McDaniel GR, Roland DA, Coleman MA. The effect of eggs shell quality on hatchability and embryonic mortality. Poultry Science 1979; 58:10-13.

McNally EH, Byerly TC. Variation in the development of embryos of hen eggs. Poultry Science 1936; 15:280-283.

Meijerhof R. Temperatura do embrião: uma nova ferramenta. Ave Word 2003; 2

Michalsky VB, Cançado SV, Lara LJC, Baião NC, Santos GC, Lana AMQ. Efeito da umidade na incubação e da idade da matriz leve sobre as relações entre o coração, o saco vitelino e o peso do pinto. Revista Brasileira de Ciência Avícola 2005a; 3(supl):12.

Michalsky VB, Cançado SV, Lara LJC, Baião NC, Santos GC, Lana AMQ. Efeito da umidade na incubação e da idade da matriz leve sobre a eclosão e parâmetros de ovos e pintos. Revista Brasileira de Ciência Avícola 2005b; 3 (supl):13.

Murakami H, Akiba Y, Horiguchi M. Growth and utilization of nutrients in newly-hatched chicks with or without removal of residual yolk. Grow, Development and Aging 1991; 56:75-84.

Nir I, Levanon M. Effect of posthatch holding time performance and residual yolk and liver composition. Poultry Science 1993; 72 : 1994-1997. $10^{\text {th }}$ European Symposium on Poultry Nutrition; 1995; Antalya. Turquia. p.21-28.

Olsen MW. The effect of age and weight af turkey eggs on the length of incubation period. Poultry Science 1942; 21:532-535.

O'Connor RJ. The growth and development of birds. New York: John Wiley \& Sons; 1984.

Pedroso AA, Stringhini JH, Leandro NSM, Xavier AS, Lima FG, Barbosa CE. Desempenho e biometria de órgãos digestórios de frangos provenientes de matrizes jovens após diferentes intervalos de alojamento. Revista Brasileira de Ciência Avícola 2005; 3(supl):5.

Reis LH, Gama LT, Soares MC. Effects of short storage conditions and broiler age on hatchability, hatching time, and chick weights. Poultry Science 1997; 76:1459-1466.

Rosa PS, Ávila VS. Variáveis relacionadas ao rendimento da incubação de ovos em matrizes de frangos de corte [comunicado técnico 246]. Concórdia (SC): Embrapa Suínos e Aves; 2000.

Salazar Al. El proceso de incubatión. Avicultura Profesional 2000;
Kingston DJ. Some hatchery factors involved in early chick mortality.

Nitsan Z. The development of digestive tract in posthached chicks. 


\begin{abstract}
Almeida JG, Vieira SL, Reis RN, Berres J, Barros R, Ferreira AK, Furtado FVF
\end{abstract}

18:26-30

SAS Institute. SAS user's guide: Ssatistics. Cary, NC; 1998.

Schmidt GS, Figueiredo EAP, Ávila VS. Incubação: características dos ovos incubados. Avicultura Industrial 2003; 8:18-24.

Shanawany MM. Inter-relationship between egg weight, parental age and embryonic development. British Poultry Scince 1984; 25 : 449-455.

Sklan D, Noy Y, Hoyzman A, Rozemboim I. Decreasing weight loss in the hatchery by feeding chicks and poults in hatching trays. Journal of Applied Poultry Research 2000; 9:42-148.

Smith KP, Bohren BB. Age of pullets effect on hatching time, egg weight and hatchability. Poultry Science 1975; 54:959-963.

Vieira SL, Almeida JG, Lima AR, Conde ORA, Olmos AR. Hatching distribution of eggs varying in weight and breeder age. Brazilian Journal of Poultry Science 2005; 7:73-78.

Vieira SL, Pophal S. Nutrição pós-eclosão em frangos de corte. Revista Brasileira de Ciência Avícola 2000; 2:189-286.

Williams C, Godfrey GF, Thompson RB. The effect of rapidity of hatching on growth, egg production, mortality and sex ratio in the domestic fowl. Poultry Science 1951; 30:599-606.

Wilson HR. Interrelationships of egg size, chick size, posthatching growth and hatchability. World's Poultry Science Journal 1991; $47: 5-20$

Wyatt CL, Weaver WD, Beane WL. Influence of egg size, egg shell quality, and posthatch holding time on broiler performance. Poultry Science 1985; 64:2049-2055.

Yannakopoulos AL. Lack of effect of ovoposition time and parental age on chick weight when egg weight remains constant. British Poultry Science 1988; 29:431-434. 